$\underline{\text { Review Article }}$

\title{
LUNG CANCER AND SMOKING IN ASIA
}

\author{
Jha R ${ }^{1}$, Weerakoon A. P. ${ }^{2}$, Karki K. B. ${ }^{3}$, Shrestha S. ${ }^{4}$, Gamage P. W. K. ${ }^{5}$ \\ ${ }^{1} \mathrm{MD}$ (Resident), Int. Medicine, Wuhan University, PR China \\ ${ }^{2}$ Research Officer, SAARC TB and HIVIAIDS, Centre, Thimi, Bhaktapur, Nepal \\ ${ }^{3}$ Training Officer, SAARC TB and HIVIAIDS Centre, Thimi, Bhaktapur, Nepal \\ ${ }^{4}$ Medical Officer, Bir Hospital, Kathmandu, Nepal \\ ${ }^{5}$ Resident, Teaching Hospital, Institute of Medicine, Tribhuban University, Kathmandu, Nepal
}

\begin{abstract}
The incidence of lung cancer is rising dramatically in Asia. Cancer is currently placed $6^{\text {th }}$ to $9^{\text {th }}$ in the common causes of mortality in the SAARC region. The most common cancers in Asia are the cancers of head, neck and thorax, which can be directly attributed to the smoking and tobacco chewing habits in the region especially SAARC region. The pattern of cigarette smoking changed globally during last three decade. It is slowly decreasing in developed countries, at a rate of $1 \%$ annually and rising in developing countries, at a rate of $2 \%$. Recent studies have shown in addition to the direct tobacco smoking, environmental tobacco smoke has a proven lung carcinogenic effect. As the single most important cause for lung cancer is tobacco smoke, every effort should be taken to control this menace.
\end{abstract}

Key Words: Lung cancer, Asia, Tobacco Smoking

\section{Epidemiology}

Lung cancer is the most frequent malignant disease and most common cause of cancer death in the world with 1.18 million deaths. ${ }^{1}$ Almost half $(49.9 \%)$ of the cases occur in the developing countries, a big change since 1980, when it was estimated that $69 \%$ were in developed countries. ${ }^{2}$ Worldwide, it is the most common cancer in men, with the highest rates observed in North America and Europe (especially Eastern Europe). In women, incidence rates are lower with a global rate of 12.1 per 100,000 compared to 35.5 per 100,000 in men. ${ }^{2}$ Mortality from lung cancer remains very high in the world. The average survival at five years in the United States is 15\%, in Europe is $10 \%$ and in developing countries is $8.9 \% .^{2}$ The situation is similar in SAARC countries. In India one year survival has been reported as 9.8 percent. $^{3}$

\section{Burden of Lung Cancer in Asia}

In 2000, there were 1.2 million deaths from cancer of trachea, bronchus and lung globally.
The rate in males was 28.8/100000, and in females 10.8/100000, with considerable regional variation. In Asia, age standardised mortality rates from lung cancer was the highest in China and the lowest in the South Pacific Islands with rates of 29.1 and 13.8/100000 in males and 14.5 and $7.7 / 100000$ in females respectively. ${ }^{4}$

\section{Trends in lung cancer mortality and incidence in Asia}

In many developed countries, lung cancer mortality has declined since 1980s. ${ }^{5}$ In developing countries, lung cancer is primarily a problem of males whereas the rates in females are low in all populations, except for those of Chinese origin. Chinese women have relatively high incidence of lung cancers compared with other ethnic groups in the region. ${ }^{6}$

A recent report from China shows a gradual increase in lung cancer rates in the past decade, mostly in men. ${ }^{7}$

In South Korea, the age adjusted mortality rate from lung cancer increased from 3.7 in 1980 to $17.8 / 100000$ in 1994 in males and from 1.4 to $7 / 100000$ in females. ${ }^{8}$ 
In India lung cancer is the leading cancer of both sexes in three of the Urban Cancer Registries (Bhopal, Delhi and Mumbai). ${ }^{9}$

A study done in Kashmir, India, using 321 lung cancer patients revealed that there was a preponderance of males $(91.9 \%)$ as compared to females (8.1\%) with male to female ratio of
11.3:1.10 In India other studies show that male to female ratio varies from 5.76:1 to 6.7:1.11

\section{Cancer pattern among males in South Asian Region}

The Age Standardized Rate (ASR) per 100,000 of top ten cancers among males in different countries in South Asia is given in Table 1

Table 1 Top Ten Cancer in South Asian Countries, Males, Year 2000

\begin{tabular}{|l|l|l|l|l|l|l|l|}
\hline \multicolumn{2}{|c|}{ India } & \multicolumn{2}{c|}{ Pakistan } & \multicolumn{2}{c|}{ Bangladesh } & \multicolumn{2}{c|}{ Sri Lanka } \\
\hline Site & ASR & Site & ASR & Site & ASR & Site & ASR \\
\hline Oral cavity & 12.8 & Lung & 20.1 & Lung & 22.4 & Oral cavity & 36.1 \\
\hline Other Pharynx & 9.6 & Oral cavity & 14.7 & Larynx & 15.4 & Oesophagus & 8.2 \\
\hline Lung & 9.0 & Bladder & 8.8 & Oral cavity & 13.4 & Other Pharynx & 6.1 \\
\hline Oesophagus & 7.6 & Larynx & 8.5 & Other Pharynx & 12.5 & Leukaemia & 5.5 \\
\hline Larynx & 6.2 & Other Pharynx & 6.7 & Oesophagus & 6.9 & Larynx & 4.5 \\
\hline Stomach & 5.7 & Oesophagus & 6.3 & NHL & 2.8 & Lung & 1.9 \\
\hline Colon/Rectum & 4.7 & Liver & 5.6 & Stomach & 1.6 & Bladder & 1.9 \\
\hline Prostate & 4.6 & NHL & 5.1 & Liver & 1.3 & Colon/Rectum & 1.8 \\
\hline Leukaemia & 3.1 & Colon/Rectum & 5.0 & Testis & 0.9 & Thyroid & 1.3 \\
\hline NHL & 3.2 & Leukaemia & 3.4 & Leukaemia & 0.9 & Stomach & 1.2 \\
\hline
\end{tabular}

Source: Cancer Awareness, Prevention and Control; Strategies for South Asia-A UCII Hand book.

According to table 1, lung cancer is the commonest in Bangladesh and Pakistan with not much of a difference in the incidence rates between themselves but double the times higher than India and ten times more than Sri Lanka.

\section{Smoking and lung cancer in Asia}

Tobacco use, especially cigarette smoking , accounts for up to $90 \%$ of all lung cancer deaths worldwide. $^{12,13}$ Fewer than $20 \%$ of cigarette smokers, however, develop lung cancer, suggesting that other factors play a role in the disease. ${ }^{14}$ Other causes of lung cancer include environmental factors such as tobacco smoke, radon and various occupational exposures. Diet and pre-existent non malignant lung disease also have been associated with the risk for developing lung cancer. ${ }^{15}$
Before the $20^{\text {th }}$ century, tobacco usually was chewed or inhaled in the form of snuff. Therefore lung cancer was rare before the $20^{\text {th }}$ century. Majority of lung cancer cases have been convincingly proved to be associated with smoking habits. The first epidemiological study on the relationship between tobacco and lung cancer was published in 1939 by several German physicians. ${ }^{16}$

After that several prospective studies worldwide have shown significantly higher cancer mortality rates among smokers than non smokers, table 2.

Table 2 Relative Risk for death from lung cancer for Men: Major Prospective studies in the World

\begin{tabular}{|l|l|l|}
\hline Study & Smoking Status & Relative Risk \\
\hline Cancer Prevention Study II & Never smoked & 1.0 \\
$(1982-1988)$ & Former smokers & 9.4 \\
& Current smokers & 20.3 \\
\hline Kaiser Permanent Medical Care Programme Study & Never smoked & 1.0 \\
$(1979-1987)$ & Current smokers & 8.1 \\
\hline Japanese study of 29 health districts & Non smokers & 1.0 \\
$(1966-1982)$ & Current smokers & 3.8 \\
\hline Swedish study & Non smokers & 1.0 \\
$(1963-1979)$ & Current smokers & 7.0 \\
\hline British doctor's study & Non smokers & 1.0 \\
$(1951-1973)$ & Current smokers & 14.0 \\
\hline
\end{tabular}


Source: US Department of Health and Human Services. A Report of the Surgeon General,. Centre for Disease Control and Prevention, Office on Smoking and Health, 2001.

Table 2 shows in current male smokers, relative risk for death from lung cancer compared with non smokers varies from about 3.8 times to more than 20 times. $^{17}$

Tobacco smoke is a complex mixture of over 4000 different chemicals, of which over 40 compounds have been evaluated by the International Agency for Research on Cancer (IARC) in animals as carcinogens. Polycyclic aromatic hydrocarbon in tobacco smoke have been shown carcinogenic to animals. ${ }^{18}$
$1 \%$ annually and rising in developing countries , at a rate of $2 \% .{ }^{19}$ With this trend, tobacco companies are directing aggressive marketing campaigns in developing countries in both Asia and Africa, targeting not only men but also women and young people. ${ }^{20}$

Figure 1 shows prevalence of smoking in adults and adolescents by sex in selected Asian and in the US and UK in the 1990s. In adults the prevalence of smoking in many Asian countries now exceeds those of the US and UK.21

The pattern of cigarette smoking changed globally during last three decade. It is slowly decreasing in developed countries, at a rate of

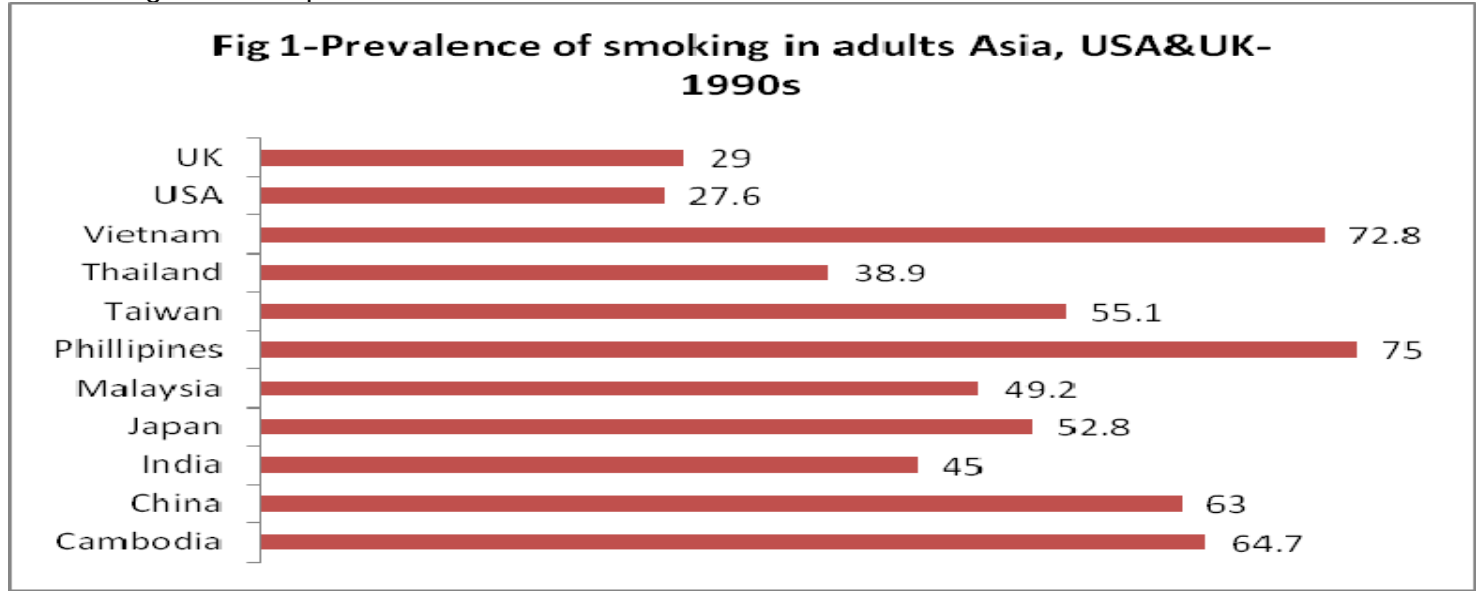

Source: Centre for Disease Control and Prevention. National Tobacco Information Online System (NATIONS), Atlanta, GA, CDC

\section{Epidemiology of Smoking in Asia}

Annual per capita cigarette consumption and prevalence of smoking in adult male and

Table 3 Annual per capita cigarette consumption and prevalence of smoking in adult male and females in SAARC countries -2001

\begin{tabular}{|l|l|l|l|l|}
\hline \multirow{2}{*}{ Country } & \multicolumn{3}{|c|}{ Prevalence of adult smoking } & \multirow{2}{*}{ Cigarette consumption(Annual per person) } \\
\cline { 2 - 4 } & Total (\%) & Male (\%) & Female (\%) & \\
\hline Afghanistan & No Data & No Data & No Data & 98 \\
\hline Bangladesh & $38.7 \%$ & $53.6 \%$ & $23.8 \%$ & 245 \\
\hline India & No Data & $29.4 \%$ & $2.50 \%, 5 \%$ & 129 \\
\hline Maldives & $26 \%$ & $37 \%$ & $15 \%$ & 1441 \\
\hline Nepal & $38.5 \%$ & $48 \%$ & $29 \%$ & 619 \\
\hline Pakistan & $22.5 \%$ & $36 \%$ & $9 \%$ & 564 \\
\hline Sri Lanka & $13.7 \%$ & $25.7 \%$ & $1.7 \%$ & 374 \\
\hline
\end{tabular}

Source: Machael J, Eriksen M. (2001) The Tobacco Atlas, World Health Organization

SAARC Journal of Tuberculosis Lung Diseases \& HIVIAIDS

female in SAARC countries -2001 are listed in the Table 3. 
According to the table 3 , the highest per capita cigarette consumption in the region is seen in Maldives, Nepal and Pakistan.

The smoking habits of Indians are different from that observed in the Western society. In India tobacco is used in various forms such as the cigarette, bidi, hooka, chutta,.chillum and pan masala. ${ }^{22}$

Bidi smoking, which is extremely common in rural India, carries a higher risk of lung cancer compared to cigarette smoking. ${ }^{23}$ (In India seven bidis are sold for every one cigarette).

In China, the estimated consumption of cigarettes per adult increased by $260 \%$ between 1970 and 1990. The rates of smoking are very high in both urban and rural areas in men, with rates of $60 \%$ and $64 \%$ and $15 \%$ and $9 \%$ in women respectively. ${ }^{24}$

Smoking cessation has been associated with a declining risk for lung cancer. The relative risk for lung cancer among former smokers begins to drop 5 years after they quit smoking and continues to drop thereafter; however, the relative risk in former smokers never reaches the risk of life -long non smokers. ${ }^{25}$

\section{Passive smoking (Environmental Tobacco Smoke (ETS)}

ETS consists of side stream smoke and the exhaled smoke of the smoker. Some known carcinogens such as benzo(a)pyrene, nitrosamine and ${ }^{210} \mathrm{Po}_{\mathrm{o}}$ are present in higher concentration in side stream smoke. ${ }^{26}$ ETS is now classified as a class A carcinogen, responsible for $20 \%$ of lung cancers in nonsmokers. ${ }^{27}$

The association between passive smoking and lung cancer risk is biologically plausible because of the similar chemical composition of smoke inhaled directly from a cigarette and smoke from a burning cigarette and the demonstration of absorption of a tobacco specific carcinogen in the urine of non-smokers exposed to cigarette smoke. 28

Hirayama 29 from Japan in 1981 reported that age - adjusted lung cancer mortality rates were lowest for wives of non-smokers, intermediate for wives of light or ex-smokers and highest for wives of heavy smokers. A meta analysis of 35 case- control and 5 cohort studies showed that the relative risk among lung cancer among non-smoking women ever exposed to ETS by their husbands was 1.2 (1.05-1.28) $)^{30}$ Rapiti et al from Chandigarh India recently reported high risk of lung cancer among those who exposed to ETS in childhood. ${ }^{31}$ Because of the low prevalence of smoking in Asian women, any misclassification bias should be small, and the Asian evidence for causal relationship between passive smoking and lung cancer is particularly strong. ${ }^{32}$

As in active cigarette smoking, the risk for lung cancer from exposure to ETS also may be influenced by genetic factors. Using archival tumour tissue from 106 women with lung cancer who were lifelong non smokers, Bennett et al revealed that those patients with significant exposure to ETS were statistically more likely to be deficient in glutathione Stransferase MI (GSTMI), an enzyme believed to be important in the detoxification of tobacco smoke carcinogen, when compared with patient without such exposure (OR-2). ${ }^{33}$

\section{Histological types of lung cancer}

Based on the biology, therapy and prognosis, lung cancer is broadly divided in to two categories.

1. Non small cell lung cancer (NSCLC)

2. Small cell lung cancer (SCLC)

Squamous cell carcinoma, adeno carcinoma and large cell carcinoma are classified as NSCLC and account for $75 \%$ to $80 \%$ of all lung cancer cases. ${ }^{34}$ 
Before 1980, the predominant cell type in lung cancer worldwide was Squamous cell carcinoma. Since then there has been gradual increase incidence of adeno carcinoma, with a corresponding decline in squamous cell cancers in many developed countries. The same changing pattern is observed in some Asian countries. In Taiwan, a study of over 10000 lung cancer cases over the period19701993 showed that the incidence of squamous cell carcinoma decreased from $46.4 \%$ to $36.2 \%$ in men, whereas adenocarcinoma increased from $30 \%$ to $36 \%$ in men. ${ }^{35} \mathrm{~A}$ similar pattern was found in Singapore, Japan, Korea and Hong Kong. ${ }^{36-39}$

However, clinical profile and histological type of lung cancer in India is different from the developed countries, in that Indian patients present almost $15-20$ years earlier, in the $5^{\text {th }}$ and $6^{\text {th }}$ decade of life 40 and squamous cell carcinoma continues be the commonest histological type. ${ }^{41}$

\section{References}

1. Parkin DM, Bray Fl, Devesa SS. Cancer burden in the year 2000:The global picture. Eur J Cancer 2001; 37 (Suppl.8): S4-66.

2. Parkin DM, Bray FI,Ferlay J, Pisani P. Global cancer statistics,2002. CA Cancer J Clin 2005;55:74-108.

3. Behera D. Managing Lung Cancer in Developing Countries: Difficulties and Solution -Editorial: Indian J Chest Dis Allied Sci 2006:48: 243-244

4. Lam WK,White NW, Chan-Yeung MM. Lung cancer epidemiology and risk factors in Asia and Africa, International Journal of Tuberculosis and Lung Disease 8(9):10451057).

5. International Agency for Research on Cancer. Lung cancer Mortality Database,Mortality data by Counties, extracted from World Health Organization Data Bank.Lyons, France.

6. Parkins DM.Cancer in developing countries. Trends in Cancer Incidence and Mortality. Cancer Surveys.1994;19/20:519-561.

7. Yang L, Parkin DM, Li L, Chen Y. Time trends in cancer mortality in China 1987. 1999.International J Cancer 2003;106:771-783
8. Jee SH,Kim IS, Suh I,Shi D, Appel LJ. Projected mortality from lung cancer in South Korea, 1980-2004. Int J Epidemiol 1998; 27:365-369.

9. Nanda Kumar A. Consolidated report of the population based cancer registries, incidence and distribution of cancer, 1990-1996. National Cancer Registry Programme. New Delhi:Indian Council of Medical Research.2001.

10. Khan NA, Afroz F, LoneMM, Teli MA, Muzaffer $M$, Jan N. Profile of lung cancer in Kashmir India: A five year study. The Indian Journal of Chest Disease and Allied Sciences.48,187190.

11. Behera $D$, Balamugesh $T$. Lung cancer in India. Indian J Chest Dis Allied Science 2004:46:269-81

12. hopland D.R: Tobacco use and its contribution to early cancer mortality with a special emphasis on cigarette smoking. Environ Health Perspect103:131-142,1995

13. Wingo P.A,Ries L.A.G, GiovinoGA, et al: Annual report to the nation on the status of the cancer, 1973-1996, with special section on lung cancer and tobacco smoking. J Natl Cancer Inst 91:675-690,1999

14. Wright GS, Gruidl ME: Early detection and prevention of lung cancer. Curr Opin Oncol 12: 143-148, 2000.

15. Richard A, Matthay MD: Clinics in Chest Medicine - Lung Cancer 23: 1 March 2002.

16. Smith $D$, Strobele $S$ A,Egger M. Smoking and health promotion in Nazi Germany. J Epidemiol Comm Health 1994;48:220-223

17. US Department of Health and Human Services. A report of the Surgeon General.Reducing Health Consequences of Smoking: Twenty five years' progress report. Department of Health and Human Services 89 -8411,1989.

18. Stanton MF,Miller E,Wrench C,Blackwell $R$. Experimental induction of epidermoid carcinoma in the lung of rats by cigarette smoke condensate. J National Cancer Institute1972;49:867-877.

19. Lam WK,White NW, Chan-Yeung MM. Lung cancer epidemiology and risk factors in Asia and Africa, International Journal of Tuberculosis and Lung Disease 8(9):10451057).

20. Mackay J, Crofton J. Tobacco and the developing world. Brit Med Bulletin 1996;52:206-221. 
21. Centre for Disease Control and Prevention. National Tobacco Information online system (NATIONS).Atlanta, GA:CDC.

22. Pathak AK, Bhutani M, Mohan A, Guleria R, Bal S, Kochupillai V.(2004) Non Small Cell Lung Cancer Current Status and Future Prospects: The Indian Journal of Chest Diseases and Allied Science :46; 192-203

23. Prasad $R$, Singh $D$, Mukerji PK, Pant MC, Srivastava AN, Kumar S. Bidi smoking and lung cancer: A case control study. Proceedings of the International Conference on Environmental and Occupational Respiratory Disease at Lucknow, 29th October to $2^{\text {nd }}$ November 9Abstract).

24. Wong XZ. Comments on 'smoking cessation in China and primary health care' $\mathrm{Br}$ Med j(Chinese edition) 2000;3:101.

25. Halpern MT, Gillespie BW, Warner KE: Pattern of absolute risk of lung cancer mortality in former smorkers (Comments).J Nat Cancer Inst 85:457-464,1993.

26. Lam WK,Du TX. Environmental inhaled agent and their relation to lung cancer. In :Loke J, ed. Patho physiology and treatment of inhalation injuries. Lung Biology in Human and Disease. Vol 34, Chapter 10. New York, NY:Marcel Dekker,1988: pp423-451.

27. National Research Council. Environment tobacco smoke: measuring exposure and assessing health effect. Washington, DC: National Academy Press, 1986:pp 209-211

28. Hecht JM, Caramella SG, Murphy SE, et al : tobacco specific lung carcinogen in the urine of men exposed to cigarette smoke. N Eng J Med 329:1543-1546,1993.

29. Hirayama T. Non-smoking wives of heavy smokers have a higher risk of lung cancer: a study from Japan .Br Med J 1981;282:183-185

30. Zhong L,Goldberg MS, Parent ME,Hanley JA. Exposure to environmental tobacco smoke and the risk of lung cancer: a meta analysis. Lung Cancer2000; 27: 3-18.

31. Rapiti $E$, Jindal SK,Gupta D, Boffeta $P$. Passive smoking and lung cancer in Chandigarh, India . Lung Cancer 1999;23:183189.

32. Lam TH, Hedley AJ. Environment tobacco smoke in Asia: slow progress against great barriers. JAMA SEA 1999;15:7-9.

33. Bennett WP et al. Environmental tobacco smoke, genetic sucessptibility, and risk of lung cancer in never smoking women. J National Cancer Institute 91:2009-2014,1999.
34. Pathak AK, Bhutani M, Mohan A, Guleria R, Bal S, Kochupillai V.(2004) Non Small Cell Lung Cancer Current Status and Future Prospects: The Indian Journal of Chest Diseases and Allied Science :46; 192-203

35. Perng DW,Perng RP, Kuo BI, Chiang SC. The variation of cell type distribution of lung cancer: a study of 10,910 cases at a medical centre in Taiwan between 1970 and 1993. Japa J Clin Oncol 1996;26:229-233

36. Seow A, Duffy SW,Ng TP,McGee MA,Lee HP. Lung cancer among Chinese female in Singapore 1968-1992: time trends, dialect group differences and implications for aetiology. In J Epidemiol 1998;27:167-172.

37. Choi J H, Chung $H C, Y o o N C$, et al. Changing trends in hidtologic types of lung cancer during the last decade (1981) -1990) in Korea: a hospital-based study. Lung Cancer 1994; 10: 287-296.

38. Lam K Y, Fu K H, Wong M P, Wang E. P. Significant changes in the distribution of histologic types of lung cancer in Hong Kong. Pathology 1993; 25: 103-105.

39. Morita T. Statistical study of lung cancer cases in the Annual of pathological autopsy cases in Japan (1958-1997). Lung Cancer 2000; 299 Suppl 1): 232.

40. Jindal SK,Behera D. Clinical spectrum of primary lung cancer. Review of Chandigarh experience of 10 years. Lung India 1990;8:9498.

41. Thippanna, Venu K,Gopalakrishnaiah V,Reddy PN, Charan BG. A profile of lung cancer patients in Hyderabad. J Indian Med Assoc 1999:97:357-59. 